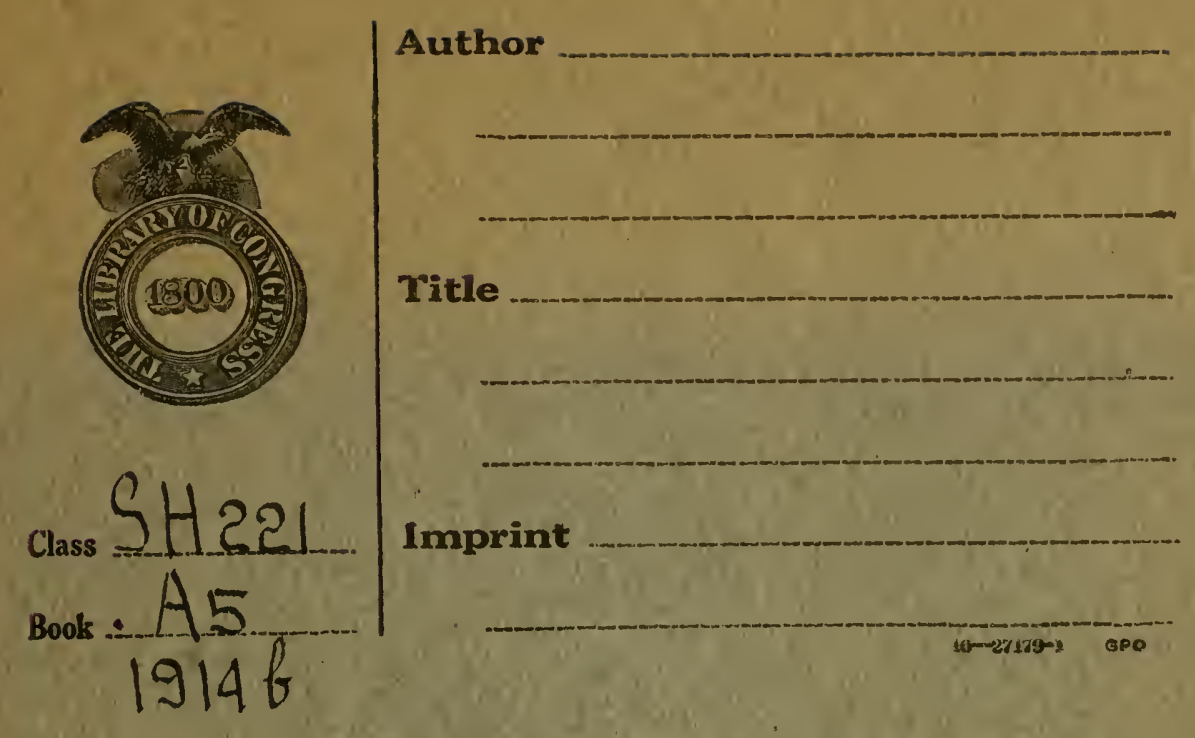





\title{
UNITED STATES-CANADA FISHERIES
}

\section{HEARINGS}

\section{BEFORE THE \\ COMMITTEE ON FOREIGN AFFAIRS}

\author{
HOUSE OF REPRESENTATIVES \\ SIXTY-THIRD CONGRESS \\ Second Session \\ ON \\ H. R. 13005 ,
}

MARCH 7 AND 13, 1914

STATEMENTS OF

DR. I. M. SMITH, HON. MARTIN B. MADIFN AND HON. JOHN A. PETERS 


\section{$S H 21$
.15
$1914 \%$}

\section{COMMITTEE ON FOREIGN AFFAIRS.}

\section{House of Representatives.}

\section{SIXTY-THIRD CONGRESS.}

(Committee room, gallery floor, west,corridor. Telephone 230.)

HENRY D. FLOOD, Virginia, Chairman.

WILLIAM G. SHARP, Ohio.

CYRUS CLINE, Indiana.

JEFFERSON M. LEVY, New York.

JAMES M. CURLEY, Massachusetts.

J. CHARLES LINTHICUM, Maryland.

ROBERT E. DIFENDERFER, Pennsylvania.

WILLIAM S. GOODWIN, Arkansas.

CHARLES M. STEDMAN, North Carolina.

EDWARD W. TOWNSEND, New Jersey.

B. P. HARRISON, Mississippi.

Robert CAtlett, Clerk.

B. F. ODEN, Assistant Clerk.
CHARLES B. SMITH, New York. JOHN R. WALKER, Georgia.

HORACE W. VAUGHAN, Texas. HENRY A. COOPER, Wisconsin. RICHARD BARTHOLDT, Missouri. GEORGE W. FAIRCHILD, New York. STEPHEN G. PORTER, Pennsylvania. IV. D. B. AINEY, Pennsylvania. JOHN J. ROGERS, Massachusetis. HENRY W. TEMPLE, Pennsylvania.

\section{OF \\ JAN 939915}




\title{
UNITED STATES-CANADA FISMERIES.
}

\author{
Committee on Foreign Afrains, \\ House of Representatives, \\ Washington, D. C., March \%, 1914.
}

The committee, being in session, proceeded to the consideration of the fisheries bill, H. R. 13005 .

Mr. Sintr. Mr. Chairman, a conference was held dormstairs in Gen. Sherwood's office in regard to this fisheries bill, and Mr. Madden, Gen. Sherwood, and others wished to make a request in connection with that bill.

Mr. Madden. A great many people, Mr. Chairman and gentlemen of the committee, have asked if it would not be possible for this committee to hear them on the desirability of modification of these regulations in the treaties between the United States and Canada relating to the fisheries question. There are so many and the interests involved are so great that it seemed to us that it would be a wise thing to hear them.

Mr. Surtr. The suggestion was made that if the committee conld hear them there might be an agreement.

The Charman. This agreement is an international agreement. How are we going to modify it? We have to reject it or accept it.

Mr. Mandex. There are tro regulations which are rery obnoxious, and it will undoubtedly, if adopted, destroy the American fisheries industry, in which several thousand men are employed and a large amount of money is invested.

The Chamman. Has the fish commission of Ohio got here?

Mr. Madden. I think not.

The Cuamian. How would it do for me to invite Dr. Hugh Smith to come orer here and have a conference with you gentlemen? him

Mr. Madnex. I think we may say we have had a conference with

The Cindruan. What about the Cinadian commissioner?

Mr. Madons. If we could get the Canadian fishmen and Dr. Smith together we might con e to some sort of agreement.

The Chammin. They might reach that agreement now. I know they contemplate making changes. Why conld we not clo that before we get the bill on the floor?

Mr. Harrison. How do you propose, Mr. Chairman, to get the bill up again?

The Cimman. We can get it up by a rule.

Mr. Townsend. Was there a proposition to have the Canadian fish commissioner come over hele?

Mr. Madnen. There was no proposition of that kind. We thought we would come and talk to you gentlemen about it, and see whether 
there was an understanding that would insure the modification of two of these regulations.

The Champan. The State Department takes the position that the schedule has to be adopted in whole or revoked.

Mr. Madden. It was not before, you know. It was adopted in modified form.

The Cmamman. Never adopted at all.

Mr. Madpen. I think it was. We could adopt it except for these two regulations.

The Champrax. If you could amend it in one particular you conld amend it in 500 particulars.

Mr. Maddex. I might say I was here last September upon another matter involved in the tariff law, and we were told, "We are sorry you came so late, but just as soon as the regnlar session comes on we will give you what you want"

The Ciramanas. They said as soon as this schedule was adopted.

Mr. Mamben. I was referring to another subject, showing how difficult it is to get action quickly. It was affecting the wine question. They said. "Just as soon as Congress convenes in regular session we will repeal the free-brandy feature of the McKinley law." It has not been repealed, and nobody up to this time has made a move.

We know you are very busy and do not wish to detain you longer. IVe just want to leave that thought with you.

(The committee therempon proceeded to other business.)

House of Representatiles,

Conmittee on Foreign Affairs. Friday, March 13, 1914.

The committee met at 10.45 o'clock a. m.. Hon. Henry D. Flood (chairman) presiding.

The Chammax. Dr. Smith, the committee wants to ask you some questions about trap nets.

\section{STATEMENT OF DR. HUGH M. SMITH, COMMISSIONER OF FISHER- IES, DEPARTMENT OF COMMERCE.}

Dr. Surth. Mr. Chairman, may I say a word or two about this Passamaquoddy Bay regulation?

The Cimamian. Ýes.

Dr. Surti. I made inquiries from men now in the Burean of Fisheries who investigated that region and whose investigation was used as a basis for this regulation, and they advised me that so far as they know at this time, and for a number of years, there are no recognized spawning grounds for herring on the American side of the border. In former years there were important spawning grounds, but those schools of spawning fish have been broken up and the recognized spawning grounds now in this region are in the Canadian waters. There are recognized spawning grounds in Passamaquoddy Bay, and the fish come in there in enormous schools and are in a spawning condition and shonld be allowed to deposit their eggs unmolested. because it is the progeny of these spawning fishes upon which depends the welfare of this whole industry, worth several 
million dollars, and I can not conceive of any reasonable objection to regulation of that kind. The principal spawning grounds for herring in this Passamaquoddy Bay region are beyond the limits of the treaty around the island of Grand Manan and further to the eastward. It was the hope of the negotiators of the treaty and of the commissioners that the limits of the treaty would be extended so as to embrace these spawning grounds, and I regard that regulation as largely precautionary.

Mr. Linthicum. Why do you mention Passamaquoddy Bay? I have not heard anything abont that.

The Charracis. Well, Mr. Peters wants to be heard about that.

Mr. Peters. Does the matter of Passamaquoddy Bay come up now?

The Ciramman. Yes, sir.

Mr. Peters. Would the committee be willing to hear me just a moment on that question?

The Chamman. Yes, sir.

\section{STATEMENT OF HON. JOHN ANDREW PETERS, A REPRESENTA- TIVE IN CONGRESS FROM THE STATE OF MAINE.}

Mr. Peters. Mr. Chairman, I represent the most eastern district in Maine, which includes Eastport and Kennebec-all that country with all its enormous fishing interests.

Many millions of dollars are invested in the canning business in that district, and since this matter has become acute I have received about a cord and a half of telegrams asking me, among other things, what is meant by the term in the regulations, "Territorial waters of Passamaquoddy Bay." Now, I have been very assiduous in trying to find out what it means and I have been talking with Dr. Smith about it, and without giving any official belief he was inclined to the belief that it was limited to a certain section of geography which I will show you on the map. This [indicating on map] is the eastern part of Maine, and right there is Eastport, and all this country is a tremendous fishing country. Of course this is Canada, New Brunswick, and the boundary line rums up through this head here [indicating] and throngh this channel up here [indicating] and up through the St. Croix River" to Passamaquoddy Bay. The "Coast Pilot," which is an anthority on maritime waters, issued by the Gorermment, bounds Passamaquoddy Bay on the sonth by Deer Island. Dr. Smith says that for an authority as to Passamaquoddy Bay boundary you should go to Dr. Tittmann. He said, "I am on the Boundary Commission, and I regard Passamaquoddy Bay as beginning with the end of my boundary line which is right here [indicating] and when I get here [indicating] I am 10 miles south of what is generally supposed to be Passamaquoddy Bay." Now, in the report of the commissioner he does not suppose that Passamaquoddy Bay comes down here as Dr. Tittmann does, evidently, because he says in the end of his report, "I would also call special attention to the recommendation"

The Cramuan (interposing). Who is that you quote?

Mr. Peters. This is David Starr. Jordan.

The Cininian. It was Dr. Smith who sicceeded him.

Mr. Peters. I suppose so.

Dr. Simtrir. Yes, sir. 
Mr. Peters. But these regulations were gotten up by Dr. Jordan.

The Chamman. Mr. Peters, what bearing does that question of the boundary line of Passamaquoddy Bay have on these regulations?

Mr. Petrers. I do not think that these regulations should go into effect until they are made certain. I believe that when there is a heary penalty imposed upon these gentlemen for violating these regulations that, at least, it onght to be makle clear to them the scope of the ter'ritory to which these regulations apply.

The Cuimman. Do you not think they would be safe against penalties for the violation of this law if the enforcement of this law was in the hands of Dr. Smith and a division under his burean, when Dr. Smith and his predecessor, Dr. Jordan, put a construction upon what is Passamaquoddy Bay?

Mr. Pexers. I think they might be as safe as some other's in the hands of Dr. Smith.

The Cunnun. But we can not make all laws fit Dr. Tittman's ideas of where the boundary line is.

Mr. Perens. Tes, sir; but at least you could satisfy us as to what the boundaries are.

Mr. Simarr. How much latitude is allowed between what you consider the strict construction under this treaty and what you consider the geographical boundary?

Mr. Péters. Abont 10 miles.

Mr. SuArp. How does that apply to the whole amount of water? Is it a matter of 5 or 10 per cent?

Mr. Perers. Oh, more than that; if the territorial waters of Passamaquoddy Bay come down here [indicating], then it would include nearly as much again as the waters of Passamaquoddy Bay.

The Chamuax. What regulation injuriomsly affects these fishermen below this line that we all think is the sonthern boundary line of Passamaquoddy Bay?

Mr. Peters. For instance, the one in regard to lobster's. 'There is a large lobster fishery there.

The Ciramian. What regulation is that?

Mr. Peters. Nos. 22, 23, 24, and 25. All of the lobster regulations.

The Chairmax. How would you change it?

Mr. Pexers. I would change it by having a specification in the regulations saying what Passamaquoddy Bay is.

The Cuamian. I mean, would you change these regulations if they did apply to these southern waters?

Mr. Peters. I do not know that I would change them at all.

The Chairman. Then what is the trouble about them?

Mr. Peters. I think the people should be entitled to know where they apply.

The CHairuax. To whom can they apply now?

Mr. Perers. They can apply to Dr. Sinith.

Dr. Surtir. That is a question of geography.

Mr. Perens. Is Dr. Smith willing to take the responsibility?

Mr. Rogens. What do you understand to be meant by the term "territorial waters"?

Mr. Peters. The only thing I can make ont of it is that it means inside of the 3 -mile limit.

Mr. Curne. I understand that Dr. Tittman is on the International Boundary Commission? 
Mr. P'eters. Yes.

Mr. Cline. Has not the boundary line been established in Passamaquoddy Bay?

Mr. Peters. The line that is going to be established runs through Passamaquoddy Bay which, he says, goes down into the Bay of Fundy.

Mr. Curne. Has the line been officially established?

Mr. Peters. I think not.

The Chamman. He is establishing the boundary line between the United States and Canada.

Mr. Peters. He is on the job now.

Mr. Cunne. That extends out to the 3-mile limit?

Mr. Perers. Yes. Now, I do not know whether these regulations about lobster's are proper for the location down there or not. I notice thàt Dr. Smith says in his hearing that these regulations are unsatisfactory and obsolete. The provision is made in this bill to immediately begin revising these regulations. Now, the revision is to be reported at the next session of this Congress-that is, in December. This bill provides that these regulations shall go into effect January 1,1915 , which is a very few days after Congress convenes, taking ont the recess. What $I$ would favor is the amending of the bill so as to delay the date at which the report shall be made to March 1, or April 1 , largely for the purpose of permitting all persons to be heard who are interested in the matter. It seems to me that no harm will result and much good will result from that, because if they are to be changed, as they clearly must be changed, why should we hurry the putting into effect of regulations which are unsatisfactory and indefinite? Why not postpone the regulations until a little later, when we will be able to examine Dr. Smith's suggestions and at the same time it will give our people an opportunity to be heard.

The Chairmax. You do not think that Congress will have an opportunity to act in December?

Mr. Péters. I do not think there will be time between the 1 st of December and the 1st of January to pass these regulations.

Mr. Cline. I'hy did not your perple raise this question before this late hour?

Mr. Peters. I do not know.

Mr. Cunne. This matter has been before Congress for the last three or four years.

Mr. Peters. I do not know, sir. I was only elected practically the other day-that is, last fall, and my predecessor died in May and I did not know anything about this matter. It is strange matter to me.

Mr. Cooper. When was this matter first called to your attention?

Mr. Peters. By a telegram a few days ago.

Mr. Cooper. How long ago?

Mr. Petwrs. I should say a week ago. I have been telegraphed and written ever since. They are writing me also in regard to whether different things are to be construed one way or the otherwhether the provision that a man can not use a dragnet or seine within 500 feet of the shore or another man's weir will supersede the State law which says he can not do it at all. But it seems to me that where the regulations are admitted to be minsatisfactory and obsolete, and where parties having such large interests as those I represent desire to be heard in revising the regulations, at least they 
ought to have the opportunity before the law goes into effect to be heard on the question of the regulations. Now, I do not oppose the principle of the bill. I suppose the main thing to be accomplished is to adopt the principle of international control of boundary waters. That principle will be sufficiently established if you pass the bill no matter whether you fix the date of the effect of the law as January 1 or April 1. There can not be any harm in allowing the present regulations to remain in force until proper consideration has been given to revising them, and there might be some harm in hurriedly putting into force new regulations like these. The principle will be put in force if we pass the bill. Let that date be January 1 , and then we will be able to get our people here to be heard.

$\mathrm{Mr}^{2}$. Cooper. Next session is the short session, and if you make the date March 1 that will necessarily carry it over to next December, the following December, becanse it will be rery easy to bring up objections in the coming December and prevent any consideration of this bill in the short session.

The Chairuan. He suggested first

Mr. Peters (interposing). The same thing would apply if the date is made May 1 instead of January 1.

Mr. Cooper. Oh, no; we might work it through.

The Chamman. Mis suggestion was first the 1st of March.

Mr. Peters. Well, I forgot about Congress adjourning.

Mr. Cooper. Well, the 1 st of March would carry it over to the following Congress.

Mr. Vaughan. Of course the regulations would go into effect if nothing was done.

Mr. Cooper. I think he said April 1.

Mr. Peters. I forgot about Congress adjourning. I said March 1.

Mr. Sharp. May I ask you this question, Mr. Peters? What, in a general way, would you say about the strictness of the Maine laws to protect all kinds of fish there?

Mr. Petwers. TVell, they are more strict in some respects than some of these regulations. For instance, we do not allow any purse seines or dragnets at all. These regulations provide that they may be used outside of the 500 -foot limit from the shore.

The Cumirmax. I just suggested to Mr. Sharp that if these regulations do not go into effect before the 1 st of March it might meet the objections of the Ohio people, as they would have the whole session of Congress to have the regulations revised.

Mr. Linturcum. That is the value of the fish in Passamaquoddy Bay?

Mr. Perers. Oh, millions of dollars-well, not in that fishery, but in Kennebec and all down there. This bill is for the purpose of preserving for future generations the fishing industry. We take a broad attitude to-day. WVe want the fisheries preserved and we believe that the only way to do it is by joint control of the boundary waters, and we believe that we should go slowly in order that justice may be done and rights may be preserved. The people down there are jealous; they say the Canadians always get the best of us in these deals. Now, we do not want the Canadians to get the best of us in these deals.

Mr. Sharp. Well, as long as we can get a treaty signed, even if it did give Canada the adrantage, wonld you not be in favor of it? 
Mr. Peters. I think we should get a treaty through.

Mr. Cooper. Do not let the sarcasm of the gentleman from Ohio affect you. You said you were perfectly satisfied with these regulations.

Mr. Peters. I beg your pardon: I did not say so.

Mr. Cooper. Except at the time

Mr. Peters (interposing). I said nothing of the kind. I said I was satisfied with the principle of the bill.

Mr. Cooper. You said that the regulations were indefinite and obsolete, but that they are all right. Then the chairman said, "If the regulations are all right, what is your objection?" And you said they were all right.

Mr. Peters. Well, I did not say that the regulations are all right. The doctor says that they are obsolete and ineffective.

The Chamman. Which ones?

Mr. Peters. Well, ask him. As far as my interest goes, they are indefinite, becanse they do not tell our fishermen whether they are violating the law when they are fishing at that point [indicating on map], or 10 miles below that point.

Mr. Cooper. If they are good regulations, if they are all right, etc. why should you object to them?

Mr. Petrers. If they were all right we would be glad to have them. but they are not all right.

The Charrian. In what particular?

Mr. Percrs. Becanse they are indefinite.

The Criarman. As to what? Passamaquorldy Bay?

Mr. Peters. Well, that is one thing.

The Cimamman. That is one thing?

Mr. Peters. Yes; that is only one thing.

Mr. Vauglian. It is not the fanlt of the regulations, but the fault of the parties disagreeing as to what constitutes Passamaquoddy Bay.

Mr. Peters. I think that is the fault of the regulations.

The Chamnan. Nobody ever heard of any disagreement until Dr. Tittman came in here and said it shonld be somewhere else.

Mr. Pexters. Well, the moment that question is raised there is a disagreement.

The Chamman. Have not all these waters down below Passamaquoddy Bay a distinct name?

Mr. Priters. No, sir.

The Cindrmax. I understand all of them have a distinct name.

Mr. Vadghan. What is Passamaquoddy Bay is a matter of fact and not a matter of definition for us.

Mr. Perers. That is what we want. We want you to say that the waters from one point to another constitute Passamaquoddy Bay. That is a matter of detail.

The Cuarruan. You know where Passamaquoddy Bay is.

Mr. Perens. Yes; but Dr. 'Tittman says I am wrong about it.

The Cimarman. What is the boundary of this water that Dr. Tittman says may be in the territorial waters of Passamaquoddy Bay?

Mr. Petrens. 'There is no mark on it. Here [indicating on map] is the island of Grand Manan. This is the Bay of Fundy. There is a mark down here 「indicatingๆ.

Mr. Chine. All you are objecting to is that we have not defineo what Passamaquoddy Bay is? 
Mr. Peters. That is all on that point.

Mr. Cline. That is a matter for the committee to determine?

Mr. Petrers. Y es, sir; in framing the regulations.

The Chaminas. ITe can not change the geography.

Mr. Peters. I assume that you do not intend to change the regulations at all in any respect on account of their being approved by both Governments.

Mr. Surti. What harm could come to your people up there if these regulations were put through as they are now?

Mr. Peters. They would be subject to fine for fishing in waters that they did not know were inclnded in the treaty waters.

The Chumsax. But you say the regulations in your State are much stricter than these regulations.

Mr. Peters. In one particular respect they are, as to fishing with dragnets.

The Chammax. Well, in what other respects?

Mr. Peters. As to lobsters and spawning grounds.

The Chairinan. There is no spawning ground down below that.

Mr. Peters. Well, there might not be, but there are surely lobster's.

The Ciraminax. Are you not satisfied that there are no spawning grounds south of that point where the disputed line is?

Mr. Peters. Well, I know that Dr. Smith says there are not, and I have great confidence in his authority. The people down there want these schools to have definite spawning grounds. These people want to know whether the Government has authority to establish a spawning ground. I do not know enough about the fishing business to know. I only know that the people down there are very anxious to be heard. All I ask is that sufficient time be given before these absolete regulations go into effect, before the new regulations are made; I ask that the bill go into effect March 1, 1915, instead of December 1, 1915.

Mr. Cuine. Would that suit you?

Mr. Peters. Yes, sir. I say that no evils can be compromised, and our people who have millions of dollars, though not at stake, are very much concerned.

Mr. FaIrchild. When does the fishing season begin up there?

Mr. Petwrs. Not before March. There will not be much fishing, anyway, in that part of the country.

Mr. Cooper. You said that you wanted to know whether the State law which prohibited the doing of certain things beyond-what limit?

Mr. Peters. The 500-foot limit.

Mr. Cooper. Would be superseded, abrogated, rescinded, or repealed by the new regulations. The regulations state:

It is muderstood by the Intemational Fislleries Commission that all statutes and laws lehating to the protection and preservation of the fisheries in the treaty waters lawfully passed, or that hereaftel may be lawfully passed, in the United States or in the Dominion of Canada, shall have full ralidity in so fal as the said statutes and laws are not in conflict with these regulations, and that these regulations shall not be construed as nelmitting fishing at any times
or places or by any methods or appliances probibited by such laws.

Now, your objection to these regulations is based on the indefiniteness as to whether or not the State law can be enforced?

Mr. Peters. No; my objection is not that, but it is that you can not tell where this line of boundary lies. I want this understood: That there are probably many other objections to these regulations 
that my people know about, but which I do not know about and that Dr. Smith does not know about.

The Crumpan. Well, let Dr'. Smith say whether he does or not. Is that your opinion, Doctor?

Dr. Sump. I made that remark in a general way, because it is well known that some of these regulations along this norther'n border are obsolete and unsatisfactory; but I did not have this particular region in Maine in mind at the time, and I do not know whether that would apply to that region.

The Cmamman. He said some of these regulations were obsolete, and he has always said that.

Mr. Peters. You propose to reexamine all these regulations?

Dr. Snitr. Yes; and redraft them where necessary.

Mr. Peters. Do you see any objection to going into it

Mr. Lintricum (interposing). Mr. Chairman, I wish to make a motion at this point. On page 2 , lines 14 and 15 , strike ont the words "January first" and insert in lieu thereof " March fifth."

Mr. Sirth. In this particular connection it does not make any difference whatever.

The Chalruan. All in favor-

Mr. Cooper (interposing). Now, one moment. Is I understand it, if we do not pass a law accepted in the terms in which it was agreed upon by the commissioner's and presented to the respective Governments, it will result in sending the whole thing back for new negotiations.

The Cummuax. The clate is fixed in the bill, but not in the regulations. 'That has never been agreed upon by the two Governments.

Mr. Lintuicum. Me fixed that date ourselves.

Mr. Cooper. I thought the Canadians fixed the date.

'The Cummux. Oh, no; they fixed upon a much earlier date some year's ago.

Mr. Silan. This bill is merely to give effect to the provisions of the treaty between the two Gorernments and prescribe the time. But, Mr. Cooper, might I reply to your statement in part by saying that we had some experience along that line in the case of fur seals, and after the dates had been fixed a number of times the time limit of the closed season, having been first fixed at 10 year's, was staved off and finally was made 5 years by the Senate.

The Charmax. That was a rather different situation. The seal skins were netting the Gorernment some revenue.

Mr. Lintmicum. The reason I suggest that amendment is this: I do not think we can adopt the new regulations by the 1st day of of January, and if we do not, but adopt them by the 1st day of March or the 5th day of March, it would be merely a question of the old regulations going into effect on the 1st day of January until the time the bill was passed. I think it would be absolutely impossible for us to pass these regulations at both ends of the Capitol before the 4 th or 5 th of March.

Mr. Cooper. That would carry the incoming of the new regulations over until next December.

Mr. Linthicum. No; if the new regulations are not put into effect then the old regulations take effect on the 5th of March.

Mr. Cool'er. But you would have no opportunity to enact the new regulations until the 1st Monday in December. 
The Champian. You would have three months.

Mr. Cooper. Not if this goes over to the 5th of March.

The Chatrman. If these gentlemen report to Congress on the first day of the session according to Mr. Linthicum's amendment we would have three months to act on their report.

Mr. Cuine. And to perfect the regulations.

Mr. Cooper. I do not understand so.' Mr. Peters has asked us to put it over so that his people would have abundant time to be heard.

Mr. Peters. To put it over until next summer.

Mr. Linthicum. They have to make their report before the first of next session, and this gives us the whole of the session.

Mr. Cooper. I understand that, but I misunderstood Mr. Peters's request.

Mr. Varguax. The old regulations will be in force until the new regulations take effect.

The Champman. Mr. Linthicum made a motion to strike ont "the 1st of January" and insert "the 5th of March," wherever it occurs in the bill, as to the time the present regulations go into effect if there is no change.

(The question was taken on Mr. Linthicum's amendment and the amendment was agreed to.)

The Chammax. Now, Mr. Peters, is that what you wanted?

Mr. Peters. Tes, sir.

\section{STATEMENT OF DR. HUGH M. SMITH, COMMISSIONER OF FISHERIES.}

The Cuarmax. Dr. Smith, the question before the committee yesterday was the suspension of regulation 48 , in reference of trap nets, until your commission could in restigate the question and report to Congress, and Congress had acted upon your recommendation. The committee wants some information about trap nets.

Mr. Listuicum. Doctor, there has been a great deal of talk about suspending the operation of regulation No. 48 until the new regulations can be adopted. Now, I have been opposing that upon the ground that they are afraid that you might not be able to get together on any new regulations as to trap nets. and in that way we would never get any regulations. But I am told that you find there is no ebjection to the use of trap nets, and if there is no objection to the use of trap nets in all international waters, then I have no objection. because I based my opinion on what you had to say on those matters.

Dr. Suntr. The trap net is not essentially different from the pound net in Lake Erie. A pound net is a net attached to stakes or piles, composed of a long leadler running from the shore, a heart or partly inclosed portion, and a final, more perfectly inclosed portion, open at the top. Now, the trap net, instead of being supported by stakes in the bottom of the river, is held in place by anchors and buoys, but the principle of its operation is identical with that of the pound net, which is recognized as a legitimate apparatus in every State in the Union.

Mr. Sharp. Could you say, Doctor, from your examination of the fisheries in the Great Lakes, why it is used in Lake Erie and not used in other lakes, and not liable to be used in other lakes if this amendment is carried? 
Dr. Smrн. Owing to the peculiar physical conditions of Lake Erie, such as do not exist in any other Great Lake, the pound net and its successor, the trap net, are used to great advantage. There were more pound nets set in Lake Erie than in any other body of water some years ago, because the nature of the bottom of the lake and the character of the fish were well adapted for that purpose. The pound net has been largely replaced by the trap nets in waters where there was doubtless orerfishing by the pound nets, because the supply of whitefish and other species in Lake Erie fell off enormously. The State of Ohio, which is concerned with trap nets more than any other State in the Union, now regards the trap net as a proper form of apparatus when recommended in proper manner, and I have been given to understand by the State anthorities that the former objections to the trap net no longer obtain, and that the trap-net fishermen will obey the laws, and there was no reason why the trap net should be regarded as a reprehensible form of apparatus. The damage which was done in former years was on account of the small size of the net and the fact that the net was concealed and did not show above the water.

Mr. Suith. I would like to ask you what you have to say as to the decrease of fish in Lake Erie, whether there has been a decrease in Lake Erie?

Dr. Surtif. There is no doubt that it fell off, due to orerfishing. There is now an apparent tendency upward.

Mr. Smitr. Will not the continuance of the trap nets tend to further decrease the supply?

Dr. Sirтн. I would not like to be understood as not favoring the regulation of the trap-net fisheries. I think the size of the mesh ought to be very carefully considered, and the number of trap nets that may be set in a line, one to another and laterally on a given section of the shore, ought to be regulated just as we hope to regulate the pound net in the same waters.

Mr. Suitr. What do you say as to whether we should amend this section 48 or leare it in, as has been suggested-

Mr. Sinnrp (interposing). Mr. Smith, that is hardly a fair question, because it is not proposed to amend but to suspend it until the commission can determine the proper way to proceed.

Mr. Smirif. What would you say as to that proposition?

Dr. Sirtur. I would personally not like to see the trap net largely wiped out, because there is a large amount of capital invested, and it has contributed a large amount of fishing for the market supplies, and, if properly regulated, I think the former objections to that apparatus would no longer hold.

Mr. Cunve. Doctor, when was your attention first called to this question with reference to the trap net? Have you ever raised any objection with your cocommissioners on this proposition?

Dr. Sirth. I have not discussed the matter.

Mr. Chine. Not at all?

Dr. Smitu. Only incidentally, because there has been no opportunity since my appointment to formally confer on these regulations.

Mr. CunNe. I want to ask you about the trap net. You are familiar with the fact that the Legislature of Ohio has provided that the meshes in the heart of the trap net shall be enlarged in 1915 or 1916 ?

Dr. Suith. I understand there was some such regulation. 
Mr. Cunse. And that is for the purpose of meeting the decreasing condition that exists there now?

Dr. Sirtir. For the purpose of preventing the destruction of immature fish.

Mr. Curne. Well, it is for the purpose of letting a great many more fish through than are now let through?

Dr. Sirtith. Yes.

Mr. Chine. And consequently it will affect the future supply?

Dr. Suith. Yes, sir.

Mr. Cuine. If that is a proper view to take of the matter, do you not think the regulations ought to be more strict than they are now with reference to fishing by trap nets?

Dr. Smith. I have no doubt in the world that the trap net, if you decide to give it any assistance at all, ought to be very carefully regulated.

Mr. Chine. I have understood that the pound net was much more effective in taking large quantities of fish ont of the water than the trap net.

Dr. Suntir. The trap net is rather a small type of pound net.

Mr. Cunve. I understand; but it is the business of the man who engages in that business to get all the fish he can.

Dr. Sintu. Undoubtedly.

Mr. Cuine. How do you explain the fact that the fishermen are now in favor of using the trap net when it is not as effective as you say the pound net is, when they want to get all the catch that they possibly can?

Dr. Surtir. The reason that the trap net has replaced the pound net to a great extent on these waters is on account of the less cost and the greater ease of manipulation.

Mr. Sharp. Is it not also because it is a portable affair and can be moved, whereas the pound net is of stationary construction?

Dr. Snith. The pound net must stay in one place.

Mr. Rogens. What is the life of these trap nets, Dr. Smith? Is there any suggestion you can make in that regard?

Dr. Surtur. That depends a great deal on the care taken by the individual fishermen, but a trap net ought to last two or three years.

Mr. Rogers. This treaty was concluded six years ago, lacking one month, and there would be probably two or three sets of trap nets bought by these fishermen since that time, since they were put upon notice of the enactment of that law. It seems to me, in view of those facts, that the argument of capital invested is not as strong as it might be considered otherwise.

The Chamman. It is cheaper. A man could establish a trap-net fishery when he could not establish a pound-net fishery.

Dr. Sintri. It is the net of the small fisherman. He can construct a half dozen trap nets where he might be able to afford only one pound net.

Mr. Vaughax. Is it not more destructive than the pound net?

Dr. Sirith. No, sir.

Mr. Sharp. Is it not a fact that the fishing business is carried on by the small men, in small numbers?

Dr. Snitu. There are a great many small fishermen. It is their sole means of livelihood. 
Mr. Cuine. Is it not a fact that the present methods used in Lake Erie by the fishermen employed in that business have been so destructive that the Government has suspended the catching of sturgeon, for instance, and some other varieties of fish, for the purpose of permitting them to increase to a sufficient number again?

Dr. Smith. The methods of fishing in that lake hare been exceedingly destructive, but I was not aware that the Government had any authority to suspend it.

Mr. Curve. Has not the Legislature of Ohio suspended the taking of black bass and sturgeon in Lake Erie for a given time?

Dr. Surtr. No black bass are allowed to be caught with any kind of net in Ohio. That is because it is a kind of food fish songht by the angler.

The Chammax. It is game.

Mr. Rogers. Can a trap net be made into a pound net?

Dr. Smrtr. Yes, sir; the leader and wings can be supported on stakes just as they are now supported.

Mr. Rogens. So that there would not be a rery great ontlay even if trap nets had to be made over?

Dr. Suitr. That is correct. The boll or heart of the trap net could not be made over into a pound net without trouble, because it only comes to the surface of the water, and the pound net extends above the surface of the water.

Mr. Rogers. Have you any idea as to the nets used in Canadian waters?

Dr. Sмiтti. The trap net is not allowed in any Canadian waters.

Mr. Cooper. That being so, that is a demonstration, is it not, that we should not have any treaty at all? Does not that give the whole case away? Canada being absolutely unwilling to permit trap nets within her jurisdiction, that ends all this, does it not?

Dr. Smirn. That is due in part to the fact that the physical conditions are not favorable for such nets.

Mr. Shanp. Is not that one of the reasons for not using them?

Dr. Sмiтн. Yes, sir.

Mr. COOOPER. Doctor, you think it is of very great importance to have a treaty with Canada for the international regulation of these fisheries?

Dr. Surтh. I regard the regulations proposed in this bill as mere details. The main thing is to recognize the principle of Federal control orer these fisheries. The regulations will come along in due time, as we gain greater experience and are able to perfect them.

Mr. Cooper. You consider it of great importance to have this attended to?

Dr. Snith. Of enormous importance; it involves $\$ 30,000,000$ in fish annually. item-

Mr. Cooper. Now, do you not think that if we strike out this

Mr. Sharp (interposing). Suspend it.

$\mathrm{Mr}$. Coorer. That is practically what it means, as legislation is carried on in this House, because we have been four years going on-

Mr. Silarp (interposing). You had better be sure that you are right. 
Mr. Cooper. I wish to say this: That the gentleman from Ohio yesterday said that perhaps I was attending to the interests of my constituents such as are on the borders of Lalie Superior; but we are very strict in the regulation of fishing, as we ought to be, and I want to say that if we amended this bill by striking out regulation 48 , we would have to start all over again, would we not, Doctor?

Dr. Sirrtr. I would not recommend striking it out. I would recommend a suspension of its operation until the two commissioners can get together and decide what is the best thing to be done. I am not responsible for these regulations. I have no pride of paternity in these regulations and it is important that I should be permitted to look over the question before I commit myself.

Mr. Cooper. We propose to substitute for the regulation adopted by the commissioners a suspension of it, which is not the thing to which Canada agreed at all. That throws the whole thing up, does it not?

Dr. Smiтr. There was a practical suspension recognized, because the date when it became effective was fixed two years ago.

The Cimmmins. Now, we have made a change in another matter. The Saginaw matter has been changed and that does not affect the regulations at all.

Dr. Smith. No, sir.

Mr. Cooper. Oh, it does not affect the regulations? The other day Dr. Smith said that the Canadian Government had ratified the regulations, and the point is insisted on that we must do likewise or else throw the whole business up and leave the question open. That is what Dr. Smith said the other day, and that is what I referred to in my question. Dr. Smith the other day was extremely urgent - were you not, Doctor? - in presenting to us the importance of passing this at the earliest possible moment.

Dr. Sмiтн. Yes, sir; and I am so now.

Mr. Cooper. And you said that Canada had ratified these regulations without any change, and the point now is that we must now do likewise or throw the whole business open again. Now, is that so?

Dr. Sмrтн. That is correct. I would regard this temporary suspension of the regulation as not contradictory of that attitude, but that is for the committee to say.

Mr. Cooper. It is a change which will not be ratified.

Mr. Sharp. Mr. Cooper, might I ask you just one question to get your view of this situation? Assume, as is a matter of fact, that these regulations were promulgated by Canada four or five years ago, at least four years ago, to meet existing conditions as they appeared to the commission, which, we will say for the sake of argument, were so, and yet those conditions have so changed as to render the making of these regulations unnecessary, because these reforms have been brought about; would you still insist that this would change the existing conditions?

Mr. Cooper. I do not think the reforms have been brought about at all. If these reforms have been brought about and the changes were made in the trap nets, then these regulations would not affect the industry at all, but the regulations specifically point out the difference between pound nets and trap nets, and Dr. Smith would seem to indicate that it is of no importance, but it strikes me that the definition is vital. 
Mr. Sharp. The regulations say that they can be used interchangeably.

Mr. Cooper. Now. I call the attention of the chairman of the committee to the definition on page 6 of the bill, which reads as follows:

Pound net: A net attached to stakes or piles, composer of a long leader ruming from the shore. a heart or partly inclosed portion. and a final, more perfectly inclosed portion. open at the top. callerl crib, ear. or pot, to which is sometimes added one or more inclosures called "spillers." On the Pacific coast a pound net is oftell called locally a "tralp."

Now, under the definition in this regulation, the interchangeable use over there would not affect what is intended in the law here, because if they had called it a trap net, it would not affect the law any, but here is what they say later in these regulations:

'Trap net: As nsed in the Great Lakes, a net similar in construction to a pound net, but with the terminal chamber or pot closed at the top and bottom.

And yet we have been told here repeatedly by men from Ohio and by Dr. Smith that there is no substantial difference between them. Why, the difference is rital. The fish in one instance get into a net that is open at the top and in the other they get into an inclosure absolutely tight top and bottom. Now, Dr. Smith said a moment ago that Canada would not permit over there anything like these trap nets, and would not have them at all. We know that they are now nsed indiscriminately in Lake Erie. Dr. Smith said the other day that the catch of white fish had decreased 80 per cent in Lake Erie.

Mr. Sharp. But they are never caught by trap nets.

Mr. Cooper. And he also said that it was of extreme importance to have this ratified at once, and that any change wonld throw it all open again. That is his express language.

The Cimarmax. He said if you do not adopt any regulation at all. if you do not pass this bill.

irr. Ponter. I understood you to say that no whitefish are caught in trap nets.

Mr. Sharr. No, sir.

Mr: Porter. Then there are no whitefish to be affected at all.

Mr. Cooper. I would like to know why a small whitefish would not run into a trap net. It is the same as any other, and nobody can make me believe to the contrary. It is immaterial how often they say it. A little whitefish will run around in a net the same as in any other place, and if he gets to a place that is closed top and bottom he will stay in there.

Mr. Ponter. Dr. Smith. how about these trap nets catching whitefish?

Dr. Sinrm. They do catch whitefish.

Mr. Porter. And to what extent?

Dr. Surrir. Not so largely as the pound nets formerly did. They catch any kind of fish that swim in the water of Lake Erie.

Mr. Sinarp. Now. Mr. Cooper, I want to reply to you a moment. I have only the word of the practical fishermen of Ohio that the whitefish are not canght in those nets. I want to reply to the observation of the gentleman from Wisconsin. IIe emphasized the fact that there is a great difference between the pound nets and trap nets, because the trap net is so fixed that it will not allow the fish to get

$34699-14-2$ 
out at the top or bottom. but he orerlooked one essential, and that is this: That it is not necessary that the fish should be able to get out at the top or bottom, because if the size of the mesh is so enlarged that ther can get ont through the sides. it does not matter whether the top or bottom is closed. As a matter of fact, I have been told during the past four or five years that there have been such agreements. We had a State senator here the other day who helped frame this law which increased the size of the meshes. So that. if that is true, the argument of the gentleman from Wisconsin is of little avail, because it does not matter that the fish can not get out of the top or bottom if there is an increase in the size of the mesh which will permit them to get out at the sides.

Mr. Cooper. That would be the sense in closing up the top and bottom if the meshes are so wide?

Mr. Porter. The game fish will jump out orer the top if it is open.

Dr. Smitir. Not many of them.

Mr. Porter. Well, I have seen some of them do it.

Dr. Smith. Not many of them. But this statement of Mr. Cooper's is not vital, because the fish do not go out of the top of a pound net; and the reason the top is left open is because it is often suspended out of the water.

Mr. Linthicum. Doctor, I want to ask you a question in regard to the use of trap nets. Will that in any way affect the fishing on Puget Sound? WVill that affect the salmon fisheries in regard to the fish getting to the spawning grounds? Will that benefit the salmon fish? The reason I ask that is because if it does it may be solely limited to Lake Erie.

Dr. Smrth. It is practically limited to Lake Erie now.

Mr. Linthicum. 'Trap nets are not used to any extent elsewhere?

Dr. Smith. No, sir; and not permitted to any extent in the Great Lakes.

Mr. Cumne. What do they take the salmon catch with?

Dr. Surtr. The salmon in Puget Sound are taken with pound rets, which are now called traps, gills nets, and purse seines, and so forth.

Mr. Cooper. I want to remind you that the other day you did not express the same views as you do now in regard to the ratification of the regulation. You wanted it ratified just exactly as Canada ratified it at that time, and you told the committee half a dozen times-here was your testimony:

The laws of the different States were adopted by the interuational commissioners and are incorporated in this section. There is no radical departure from existing legislation on behalf of the States. In some cases the States were unable to act, but as far as they do, these regulations have really been strongly indorsed by the States. I have letter's from the proper officials of all the boundary States, with perhaps one exception, strongiy advocating this bill or a similar bill that will give effect to the treaty.

Dr. Surtu. This regulation would never have been put in this schedule if it had not been for the insistence of the Ohio authorities, who at that time were strongly opposed to the trap net.

Mr. Cooper. Well, is that so? It was put in at the urgent solicitation of Ohio and subsequently indorsed by all the other States?

The Chimrian. That has been stated here a half a dlozen times.

Mr. Cooper. I did not know that. I have not heard it. 
The Champax. There has been a change in the construction of the trap nets and Ohio's position has changed.

Mr. Coopen. And all the other States asked for it. and Canada did not want to have the trap net. It looks to me like local interests against the interests of the general public. I am perfectly frank in saying that.

The Chalrus. We have a fish commissioner here who favors trap nets. The Canadian commissioner might not faror trap nets. We have adopted a regulation prohibiting trap nets. and I am unwilling to put our "commissioner entirely within the power of the Canadian commissioner when he stands up here and savs that he is in favor of a trap net.

Mr. Arner. Properly regulated.

Mr. Sranp. In order to get this matter before the committee I move the adoption of this amendment to the bill:

Prorided also. That the enforcement of regulation No. 45 is suspended pending revision by the international frisheries Commission and the aplmoral of said revision by Congress.

That is to be inserted on page 3 , section 1 , after line 3.

Mr. Linthicum. Mr. Chairman, I offer an amendment to that amendment, to add to the amendment these words:

But this shall in nowise preclucte sain commission from regulating the construction and operation of trap nets.

It appears to me from what the doctor says that they do not want to be precluded from the regulation of trap nets, and by adding that amendment I think it would give them the right to control and regulate the use of trap nets wherever they are used.

Mr. Sirarp. I accept that amendment. "That puts it into the hands of the commission to regulate its use and prescribe regulations for its use.

Mr. Anney. What is the conclusion of Dr. Smith as to whether or not this bill, if passed in the form as amended, would necessitate going back to the Dominion Parliament for approval.

Dr. Smitr. I think the bill as amended would not have to be submitted to Parliament, because the regulations are almost identical with the regulations passed by Parliament, except some change in the date.

Mr. Anner. Did you observe the phraseology of the amendment to the amendment that Mr. Linthicum suggested?

Dr. SuIтH. I did not construe it.

Mr. Aner. I would like to have the amendment and the amendment to the amendment reported again and invite the attention of the doctor to them.

(The amendment and the amendment to the amendment were again reported.)

Mr. Anner. There is an authorization to the commission that it seems to me is quite different from a suspension of the operation of certain of these rules. Personally, I can not see why that would require the matter to be sent back to Parliament.

Mr. Sharp. But does not the bill itself. Mr. Ainey. contemplate that this regulation shall be made by that commission?

Dr. Surth. This amendment gives much larger powers to this commission than are conferred by any other part of the bill.

Mr. Linthicum. It does not give you power 
Mr. Rogers (interposing). Suppose that that amendment should say that sections 1 to 48 should be suspended pending negotiations. Could it be said that that could not be taken up by the Dominion authorities? It does not make any difference how small the amendment is, if it covers anything involved in the treaty the result is that the whole thing will be thrown wide open, which Dr. Smith said the other day he was extremely anxious to a void.

The Chammax. Well, nobody took that position as to Saginaw Bay, and this bill requires this commission to get together and their report will be here by the next Congress.

Mr. Rogers. I am not certain but what that same argument would not apply to Saginaw Bay.

The Chamma. It seems to me that we ought to have Dr'. Smith's opinion as to $\mathrm{Mr}$. Ainey's suggestion.

Mr. Chive. I rould like to ask Dr. Smith a question for information. It seems to me an absurd proposition to suspend the operation of the device and then to confer authority to regulate it.

Mr. Porter. They prohibit the use of trap nets and then suspend the operation of that prohibition, and that leares the power in the hands of the commission to regulate it.

Mr. Cunse. What are you going to regulate? Something that you can not use after you regulate it?

Mr. Porter. The prohibition against its use is suspended, and if Mr. Linthicum wants to regulate it

Dr. Surth (interposing). This gives the porrer to the commission which Congress has reserved to itself.

Mr. Cuine. Personally I would like to protect our folks on this side of the line, but I also want to see this treaty carried ont, and I would like to supplement Mr. Ainey's inquiry by asking from you, Doctor, whether, if we passed this sispension now, it will not vitiate the whole agreement, so far as Canada is concerned, and ourselves, too, until the matter is referred back to both legislative bodies for approval? I mean Mr. Sharp's amendment.

Dr. Sinth. I have not so regarded it. but I would not like to pose as an anthority on a matter of that kind.

Mr. Anner. On the answer to that question depends the way in which I shall rote on this proposition.

Mr. Cooper. If one man suggests to another a proposition for a contract, a written contract, the other man can not send it back accepting everything except some little point in it. The minds must agree entirely on the proposition, otherwise the whole proposition is up in the air.

Mr. Sharp. What would you suggest in reference to the Maine proposition?

Mr. Cooprr. I have a suggestion right here. The treaty is a contract. Of course, it can be set aside by the law of Congress. Under the Constitution it is made the law and can be set aside subsequently, of course, but until it is repealed it is the law. Now, they make a law exactly like it in Canada, and the mutual agreement is such that it shall be a uniform agreement between the two nations. Article 2 of the treaty says:

It shall be the duty of this Intelnational Fisheries Commission, within six months after being nimed, to prepare a system of uniform and common international regulations. 
These commissioners liave met pursuant to that treaty, and pursuant to that article have fixed these regulations in a certain form. So far as the trap net is concerned, it is prohibited entirely after the 1st day of Jannary, 1916, and Canada has passed that law. It is pretended that we can go to work and suspend the going into effect of the regulation agreed upon under that treaty in spite of the language of article 2-

A system of uniform and common international regulations.

It is just as different from the Canada regulation as it is adopted as it can be. There is an absolute prohibition in the Canada agreement, and we propose to modify that. notwithstanding. What did Dr. Smith say the other day in his testimony? He said:

The Canadian Gorermment has ratified these regnlations, and the point that is insisted on now is that we must do likewise or else throw the whole business open again.

Mr. Srarre. Would you say that our action a few moments ago in reference to the Maine situation would necessitate referring the whole matter back again?

Mr. Cooper. I think, if there is anvthing that can be looked upon as a modification of the regulation. the other party to the treaty would have an absolute right to consider it. and the whole thing will be up in the air.

Mr. Sharp. Well, will the matter upon which we passed a while ago have an effect-

Mr. Cooper (interposing). Oh, that is an arbitrary date.

$\mathrm{Mr}$. Sharp. But we do not prohibit the use of trap nets

Mr. Cooper (interposing). No; but youl change the agreenent which Canada made with us.

The Chamman. If your position is correct. we have destroyed the treaty, because we have stricken ont Saginam Bay. The Canadian Parliament adopted these regulations applying to Saginaw Bay. and we have stricken that out of these regulations.

$\mathrm{Mr}_{r}$. Cooper. Mr. Chairman, we did that becanse we were assured here

The Chamarax (interposing). No: we were not. We had no asstrances whatever. It will not have to go back to the Canadian Parliament.

Mr. Cooper. The only reason we passed it is this: We were assured that the Canadian commissioner and the United States commissioner had agreed that Saginaw Bar ought to go out: but the United States commissioner has no authority to bind the Canadian commissioner.

The Champian. Not at all.

Mr. Cooper. That might not meet with the approval of the Canadian Government.

The Chammax. But we never thought it would have to go back to be ratified.

Mr. Cooper. Well, there can not be any modification of a treaty by one party withont the other party agreeing to it. Mr. Chairman, do you think that after the United States Government has agreed with the Canadian Government that certain things shall be done that the Canadian Parliament has the right to modify the doing of those things? 
The Charmar. I think we can adopt a set of regulations and we can modify them if the modifications do not affect the situation of the other party.

Mr. TAUGHN. If the suspension of putting into effect all of the provisions until the 5th day of March. as we have already done, does not necessitate the throwing up of the whole thing, why should the suspension of one of them-

Mr. Sharp (interposing). One out of sixty-six.

Mr. Vaughan. In other words, we have only postponed or deferred the going into effect of all these regulations until the 5th of March, and that necessarily inclucles the right to suspend the operation of any one of them, and if we can suspend the putting into effect of all of them until the 5th of March, certainly we can suspend the operation of any one of them until any time we choose, without malring it necessary to go back to the Canadian Parliament for ratinication.

Mr. Rogers. Mr. Chairman, that argument is entirely unsound, if the gentleman from 'Texas remembers the language of the treaty. The treaty provides:

The present convention shall be duly ratified by the President of the United States, by and with the atrice and consent of the Senate thereof, etc.

The Chamman. That was done.

Mr. Rogers. Now, the question comes up in regard to giving effect to the provisions of the treaty. There is no date provided in the treaty when that can oceur. It can occur in 10 years or 15 years or 100 years, provided that in the meantime Canada does not withdraw its ratification. So that we could have selected 1912 or 1913 or 1915 as the date for the going into effect of the provisions of the treaty, but whatever day we selected we have to meet the mind of the Canadian Government and enact what they have enacted or else it all goes back to them.

The Chamman. Well, they might repeal that law.

Mr. Cooper. Dr. Smith said the other day that we could not change the regulations without-

The Chairian (interposing). Well, we have not changed the regulations.

Dr. Surtr. Would not the position of Canada be exactly the same in case Canada amended one of these regulations? If it was material we might reject the whole thing, and if it was not material we would $110 t$.

Mr. Sharp. 'That is right.

Mr. Linthicum. I ask leave to substitute this amendment for the amendment I offered a while ago:

But said commission shall have the right to regulate the construction and operation of trap nets.

I did not realize before that there was any recognition of trap nets.

Mr. Sharp. I think we have the right to do that anyway.

Mr. Lintinicum. I do not know.

Mr. Sharp. We will not have that right if the trap nets are absolutely stricken out.

Mr. Linthicum. Doctor. have you the right at present to regulate the construction and operation of trap nets?

Dr. Surtr. Only in this section 48.

Mir. Iaxthicum. But that is mispended. 
Mr. Vaughr. But dees the law give you the right to suspend this regulation?

Dr. Sintr. Only when provided by Congress.

Mr. Ansy. I would like to know whether we have not before us, oi in the files of the committee, a copy of the bill as passed by the Dominion Parliament. The phraseology of that law might throw some light on the manner of the approval of these regulations. I notice that in the hearings we have just a statement from Dr. Smith that these regulations were approred by Parliament.

Mr. Cooper. He said no change had been made by Parliament.

Mr. Ansex. But our bill is what we are now liscissing. and not the regulations. I would like to ask how the-e regulations were adopted by the Canadian Parliament?

Mr. Cooper. He says just as they are here.

Mr. Arnex. Well, we ought to have the phraseology of the bill that was introduced and passed by Parliament.

Mr. Sirarp. I want this bill passed. 'This whole industry ought to be regulated, but I have no reason to beliere that the statement of Dr. Smith is incorrect. The people of Ohio did demand this regulation, but conditions are changed and I doubt whether the Canadian people would stand out for the enforcement of this regulation when the Ohio authorities say that there is no longer existing the evil covered by that particular regulation, and therefore onr objection is withdrawn. How could the Canadians insist upon it in the face of the withdrawal of the objection by the people who first insisted upon it?

Mr. Cline. That is only speculation.

Mr. Sinare. Well, the speculation is so remote-

Mr. Chine (interposing). Do you not understand that the people who make the regulations shall have the right to say what the regulations shall consist of?

Mir. Lintuicum. Under this bill the trap nets were entirely stricken out-

Mr. Curne (interposing). Oh, take anything else that is in the bill.

Mr. Lintricun. The commission had the right to regulate all other kinds of nets that are allowed according to these regulations. The commission had the right to regulate the construction and operation of them, but trap nets being disallowed, they can not regulate the operation of them.

Mr. Cums. If they have the right to put in trap nets, they certainly have the right to regulate them.

Mi. Sirth. The bill provides:

That no further or other regulations or amendments thereto under the provisions of said treaty of April 11, 1908, shall be adopted or have the force or effect of law without action by the Congress of the Uniterl States.

That would seem to prevent us from doing it.

Mr. Linthicum. I think that is very essential if you are going to leave trap nets in the bill.

The Crumruan. I notice on page 13, regulation 5.9, as follows:

No trap nets shall be used for the capture of fish in these treaty waters.

So, if we suspended regulation 48 it would leave things just as they are now.

Dr. Surth. That applies to the Lake of the Woods, Rainy Lake, and Rainy River. 
Mr. Sharp. I ask for a rote.

(The question was taken on the Linthicum substitute amendment, and the chair announced that the ares had it.)

Mr. Cooper. Mr. Chairman, in view of the importance of this matter. $I$ ask for the ayes and noes on this amendment.

The Chamman. All in faror of Mr. Linthicum's amendment will answer "aye."

Mr. Titghr. Before I rote I would like to ask Dr. Smith a question. Doctor, under the law creating this commission, has the commission power to prescribe regulations to be approved both by the Canadian Government and by the United States Government in the matter of trap nets? Has the commission already the power to adopt regulations governing the use of fish traps?

Dr. SnITH. The only power they have is conferred by Congress.

Mr. Thens. And by the treaty.

Dr. Sunтн. But the treaty does not give the commission any power to make regulations. It can only recommend regulations for the approval of the respective Gorernments.

Mr. SHARP. I have no objection to it except that it might complicate the whole matter to such an extent that I would not like to vote for it.

(The roll was callerl. and the following member's voted "aye": Messis. Cline, Linthicum, Difenderfer, Stedman, Smith, Walker, Tanghan. Fairchild. and Porter. The following roted "no"? Messrs. Cooper. Ainey. and Rogers.)

The Crampras. Now, the question is on the original amendment offered by Mr. Sharp.

MIr. Cooren. I ask for the ayes and noes.

Mr. Rogers. I thought we were roting on the main question, and I should like to withdram my rote of "no" and vote "aye" on the amendment to the amendment.

The Crumpux. Without objection, the change will be made.

(The question was taken on the Sharp amendment, and the follorring members voted "are": Messrs. Sharp, Cline, Linthicum, Difenclerfer, Stednan. Snith. Walker, Vanghan. Fairchild, Porter, Rogers. and the chairman. The following roted "no": Messrs. Sharp. Cooper. Ainey, and Rogers.)

Mr. Arney (when his name was called). Mr. Chairman. I shall have to rote "no" on that, because I am fearful that it would interfere with the treaty.

Mr. Listhicum. Mr. Chairman, my amendment reads, "but said commission shall have the right." etc. I think it would be better to make it "the commission " instead of "said commission." I ask unanimous consent to make that change.

The Chamman. Withont objection the change will be made.

Mr. Cooper. I wonder if the members of the committee want that to become a law without the consent of the Canadian Parliament?

The Crampatan. Giving the porer to this commission?

Mr. COOper. The commission is to recommend a new style of trap net. and we make it go into effect

Mr. Shanp (interposing). Are you not willing to have the American Congress say how it shall go into effect?

Mr. Cooprr. Provided the Canadian Parliament agrees to it.

(Therenpon the committee adjourned.) 


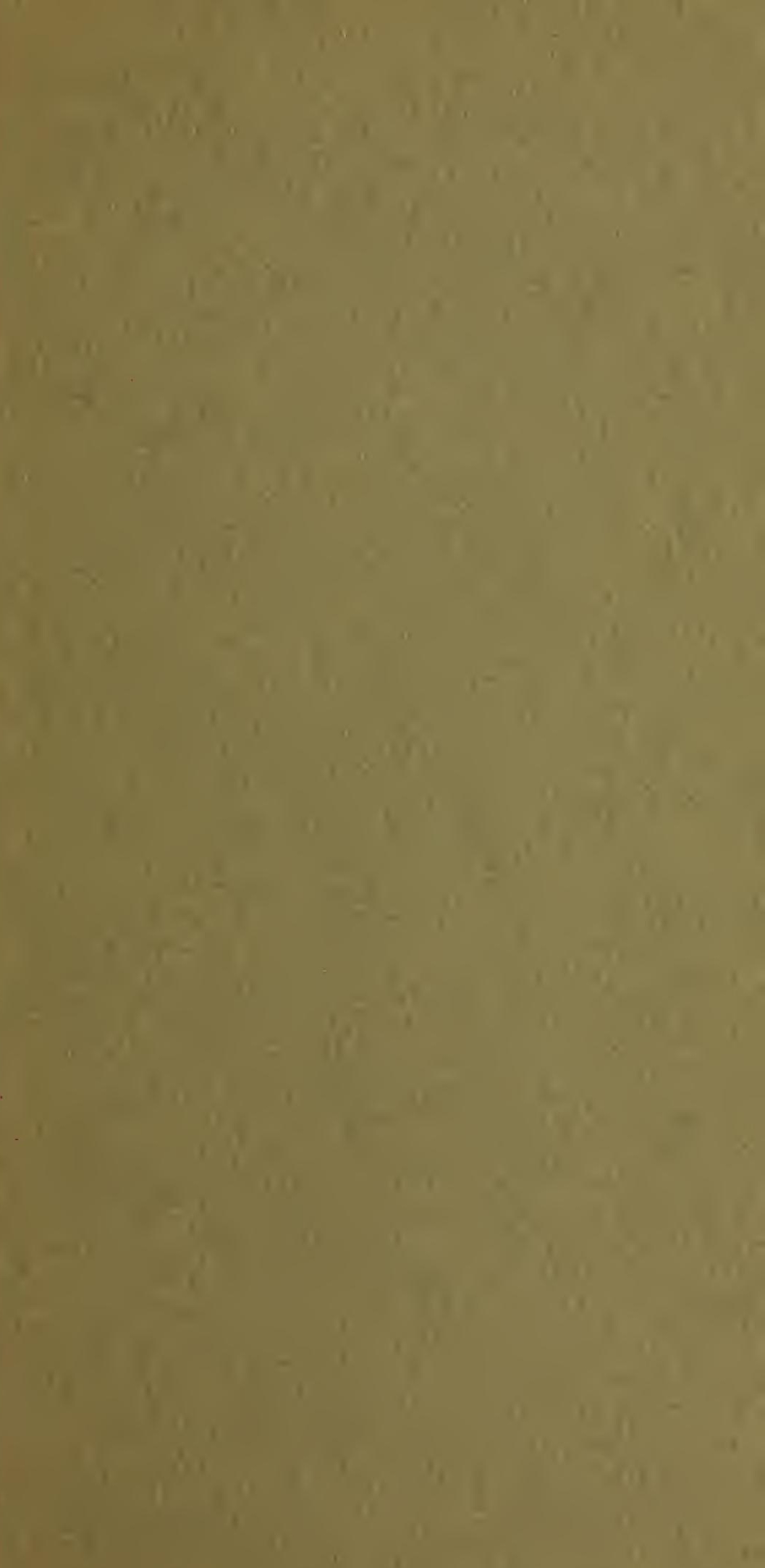




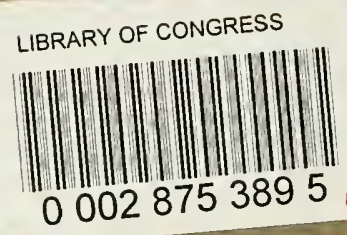

